\title{
The effect of demethylasterriquinone B-1 on insulin secretion in rat pancreas
}

\author{
Min-Chuan Lai ${ }^{1,2}$, Yu-Shan Lo ${ }^{1}$, Chi Yang ${ }^{1^{*}}$ \\ ${ }^{1}$ Department of Veterinary Medicine, College of Veterinary Medicine, National Chung Hsing University, Taichung City, Chinese \\ Taipei; ${ }^{*}$ Corresponding Author: cyang@dragon.nchu.edu.tw \\ ${ }^{2}$ Bureau of Animal and Plant Health Inspection and Quarantine, Council of Agriculture, Taipei City, Chinese Taipei
}

Received 18 April 2013; revised 20 May 2013; accepted 28 May 2013

Copyright (C) 2013 Min-Chuan Lai et al. This is an open access article distributed under the Creative Commons Attribution License, which permits unrestricted use, distribution, and reproduction in any medium, provided the original work is properly cited.

\section{ABSTRACT}

A small nonpeptidyl compoud extracted from Pseudomassaria sp. was found to induce the activity of human insulin receptor tyrosine kinase in vitro. The compound was identified as demethylasterriquinone B-1 (DMAQ-B1). DMAQ$B 1$ also induced an increase in [Ca2+]i and insulin secretion in mice pancreatic beta-cells at low glucose ( $3 \mathrm{mM})$ concentration via insulin receptor substrate-1/phosphatidylinositol-3kinase (PI3 kinase) pathway. By using rat pancreatic perfusion technique, we found that $10 \mu \mathrm{M}$ DMAQ-B1 directly stimulated insulin secretion up to $240 \%$ in normal rat pancreas. In the dosage from 1 to $20 \mu \mathrm{M}$, DMAQ-B1 stimulated insulin secretion in a dose dependent manner. Furthermore, DMAQ-B1 enhanced glucose-induced insulin secretion by $17.6 \%$ (first stage) and $19.0 \%$ (second stage), respectively. The PI3 kinase inhibitors, LY 294002 (3.9 $\mu \mathrm{M})$ or wortmannin (100 $\mathrm{nM})$, inhibited DMAQ-B1-induced insulin secretion by $46.3 \%$ and $57.4 \%$, respectively. LY 294002 or wortmannin also inhibited DMAQ-B1 with 10 $\mathrm{mM}$ glucose-induced insulin secretion by $\mathbf{7 0 . 3 \%}$ and $79.0 \%$, respectively. All the results suggested that DMAQ-B1 directly stimulated insulin secretion and enhanced glucose-induced insulin secretion. The effect of DMAQ-B1 may mediate through the activation of PI3 kinase pathway to stimulate insulin secretion in normal rat pancreas.

Keywords: DMAQ-B1; Insulin Secretion; PI3 Kinase; Tyrosine Kinase; Wortmannin

\section{INTRODUCTION}

Oral therapies for type 2 diabetes mellitus are widely used until today. Thus, the development of an orally insulin mimetic drug was the way for the treatment of diabetes mellitus. In order to discover a new compound that could activate the human insulin receptor tyrosine kinase, Zhang et al. established a cell-based assay to screen a collection of synthetic chemicals and natural products extracted from fungus [1]. Following the analysis with high-performance liquid chromatography and nuclear magnetic resonance, a small nonpeptidyl compound isolated from Pseudomassaria sp. was characterized and identified as demethylasterriquinone B-1 (DMAQ-B1), and also named as L-783, 281 [1]. It was found that DMAQ-B1 had hormone-like action in vitro. DMAQ-B1 increased the activity of human insulin receptor tyrosine kinase and increased the tyrosine phosphorylation of IR subunit. DMAQ-B1 also activated insulin receptor tyrosine kinase downstream signaling proteins, including insulin receptor substrate 1 (IRS-1), ERK1/2, SHC, Phosphatidylinositol 3-kinase (PI3 kinase), p70 S6 kinase, Akt and glycogen synthase kinase-3 (GSK-3) [13]. DMAQ-B1 also induced an increase in $[\mathrm{Ca} 2+] \mathrm{i}$ involved release of $\mathrm{Ca} 2+$ from intracellular stores and stimulated insulin secretion in mice pancreatic beta-cells at nonstimulatory glucose $(3 \mathrm{mM})$ concentrations via insulin receptor substrate-1/phosphatidylinositol-3-kinase (PI3 kinase) pathway [4]. In addition, DMAQ-B1 could improve glucose intolerance and inhibit hyperinsulinemia in $\mathrm{db} / \mathrm{db}$ and ob/ob mice [1]. Strowski et al. found that administration of DMAQ-B1 could decrease hyperglycemia and obesity in a nongenetic mouse model of type 2 diabetes mellitus [5]. Velliquette et al. found that the oral treatment of DMAQ-B1 didn't increase body weight and food intake in the spontaneously hypertensive obese rat model of metabolic syndrome X [6]. Chronic 
treatment with DMAQ-B1 had no significant effect on the maximal insulin-induced insulin receptor tyrosine phosphorylation or IRS-1- associated PI3 kinase activity in skeletal muscle in vivo [6]. According to previous studies, we explored the direct effect of DMAQ-B1 on insulin secretion and the potential signaling mechanism of stimulatory effect of DMAQ-B1 by using an isolated rat pancreas perfusion system.

\section{MATERIALS AND METHODS}

\subsection{Animals and Chemicals}

Sprague-Dawley rats (200 - $300 \mathrm{~g})$ originated from BioLasco Taiwan Co., Ltd were kept at room temperature $\left(\sim 25^{\circ} \mathrm{C}\right)$ in plastic cages under a 12-h cycle of light. The rats were given free access to tap water and were fed ad libitum with commercial diet (Fwusow; Sha-Lu, Taichung, Taiwan). After an overnight fast ( $>12 \mathrm{hr}$ ), rats were anesthetized with a $125 \mathrm{mg} / \mathrm{kg}$ intraperitoneal injection of Urethane (Fluka Chemie Gmbh, China). Access to the pancreas was gained through a ventral midline incision, and the animals' celiac arteries and portal veins were cannulated with polyvinyl tubing's of 0.625 and 1.2 $\mathrm{mm}$ (internal diameter), respectively. The rats were maintained at $37^{\circ} \mathrm{C}$ throughout the experiments. KrebsRinger bicarbonate buffer supplemented with $10 \mathrm{mM}$ $\mathrm{N}$-2-hydroxyethylpiperazine-N-2-ethanesulfonic acid (HEPES), $5.5 \mathrm{mM}$ glucose, $0.1 \%$ dextran, and $0.2 \%$ bovine serum albumin, was used as the perfusate (basal medium). This solution was continuously aerated with $95 \% \mathrm{O}_{2} / 5 \% \mathrm{CO}_{2}$, and the $\mathrm{pH}$ value was maintained at 7.4. All chemicals were purchased from Sigma Chemical (St. Louis, MO), except for DMAQ-B1, dimethylsulfoxide (DMSO) and LY294002, which were provided by Merck (U.S. and Canada), Merck (Darmstadt, Germany) and Eli Lilly (Indianapolis, IN), respectively. DMAQ-B1 was dissolved in $100 \mu \mathrm{M}$ DMSO. The animal use protocol was reviewed and approved by the Institutional Animal Care and Use Committee of National Chung Hsing University.

\subsection{Pancreatic Perfusion}

By using a method modified from Grodsky and Fanska [7], the in situ in living rat pancreatic perfusion with an open system was performed at $37^{\circ} \mathrm{C}$. The pancreatic perfusion was maintained at a flow rate of $1 \mathrm{ml} / \mathrm{min}$, which did not cause noticeable edema or impair insulin release. After the cannulation of celiac artery and portal vein, the rat pancreatic perfusion preparations were perfused with KRB basal medium for $20 \mathrm{~min}$ as an equilibration period. Subsequently, the effluent fluid was collected every minute from the cannula of the portal vein for $50 \mathrm{~min}$. In experiment 1 , after a baseline period of 10 min, the perfusate containing DMAQ-B1 $(10 \mu \mathrm{M})$ or
DMSO $(100 \mu \mathrm{M})$ was administered for $30 \mathrm{~min}$, followed by the basal medium for $10 \mathrm{~min}$. In experiment 2 , after a baseline period of $10 \mathrm{~min}$, the perfusate containing DMAQ-B1 $(1,5,10,15$ or $20 \mu \mathrm{M})$ was administered for $30 \mathrm{~min}$, followed by the basal medium for $10 \mathrm{~min}$. In experiment 3 , the perfusate containing $10 \mathrm{mM}$ glucose with or without DMAQ-B1 $(10 \mu \mathrm{M})$ was administered for $30 \mathrm{~min}$, followed by a basal medium washout for the last $10 \mathrm{~min}$. In experiment 4, the medium containing PI3K inhibitors (3.9 $\mu \mathrm{M}$ LY294002 or $100 \mathrm{nM}$ wortmannin) was administered for $5 \mathrm{~min}$ and was followed by LY294002 $(3.9 \mu \mathrm{M})$ with DMAQ-B1 $(10 \mu \mathrm{M})$ or wortmannin(100 $\mathrm{nM})$ with DMAQ-B1 $(10 \mu \mathrm{M})$ for another 25 min, respectively. In experiment 5 , the medium containing LY294002 $(3.9 \mu \mathrm{M})$ was administered for $5 \mathrm{~min}$ as pretreatment and was followed by LY294002 $(3.9 \mu \mathrm{M})$ with DMAQ-B1 $(10 \mu \mathrm{M})$ or LY294002 $(3.9 \mu \mathrm{M})$ with DMAQ-B1 $(10 \mu \mathrm{M})$ and $10 \mathrm{mM}$ glucose for another 25 min. In experiment 6 , the medium containing wortman$\operatorname{nin}(100 \mathrm{nM})$ was administered for $5 \mathrm{~min}$ as pretreatment and was followed by wortmannin $(100 \mathrm{nM})$ with DMAQ-B1 $(10 \mu \mathrm{M})$ or wortmannin $(100 \mathrm{nM})$ with 10 $\mathrm{mM}$ glucose and DMAQ-B1 $(10 \mu \mathrm{M})$ for another $25 \mathrm{~min}$. The collected effluent fluid was kept at $4{ }^{\circ} \mathrm{C}$ and subsequently assayed within $12 \mathrm{~h}$ for insulin by using radioimmunoassay (RIA), as previously described by Hale and Randle [8]. Rat insulin was used as standard for the RIA.

\subsection{Data Expression and Statistical Analysis}

Data of effluent insulin concentrations were expressed as percentage of the baseline level (mean of 10 baseline values) in means \pm SE. Data were analyzed by using analysis of variance (ANOVA) to determine the significance of treatment and time. The treatment multiplied by time interaction was used as an error term to determine the effect of treatment. The significance of treatment was determined from the conservative $\mathrm{F}$ value. Tukey's highly significant difference test was used to determine the differences between treatments for which the ANOVA indicated a significant $(\mathrm{P}<0.05) \mathrm{F}$ ratio. For analyzing the first and second phases of insulin secretion during glucose perfusion, the areas under the curve (AUCs) of the percentage increase over baseline were calculated and compared by using Student's t tests. P < 0.05 was considered statistically significant.

\section{RESULTS}

\subsection{Effect of DMAQ-B1 on Insulin Secretion}

The direct effect of DMAQ-B1 $(10 \mu \mathrm{M})$ on insulin secretion in normal living rat in situ pancreas was shown in Figure 1. The increase of insulin secretion was observed 


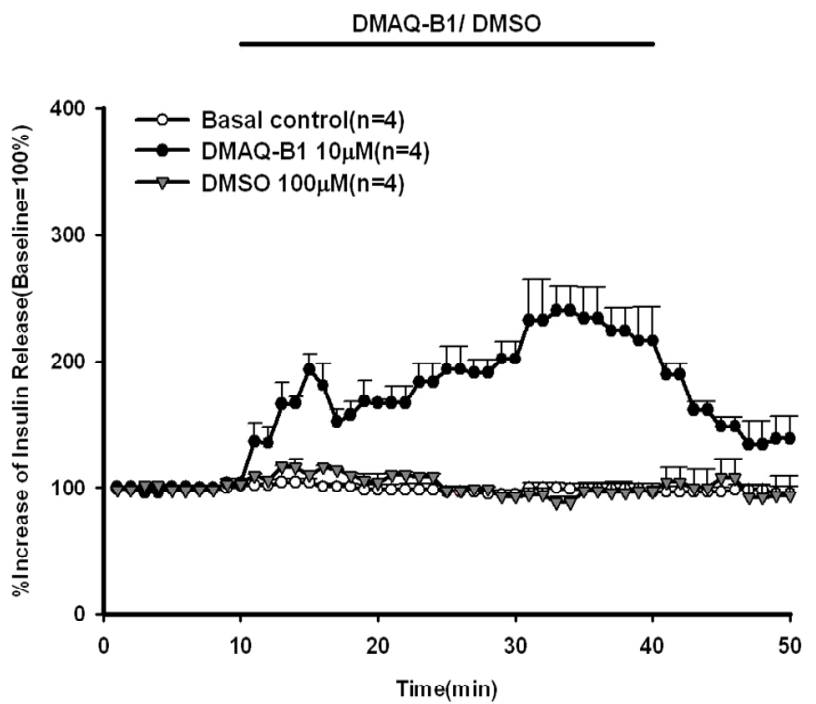

Figure 1. Effect of demethylasterriquinone B-1 on insulin secretion in the perfused rat pancreas. In pancreatic perfusion experiments, an equilibration period of $20 \mathrm{~min}$ preceded time 0 . After a baseline period of $10 \mathrm{~min}, 10 \mu \mathrm{M}$ DMAQ-B1 and 100 $\mu \mathrm{M}$ DMSO were administered for $30 \mathrm{~min}$ followed by the basal medium (KRB), respectively. Values are shown as means $\pm \mathrm{SE}$ $(\mathrm{n}=4)$. The baseline effluent concentrations of insulin were $4172 \pm 277 \mathrm{pg} / \mathrm{ml}, 1385 \pm 265 \mathrm{pg} / \mathrm{ml}$, and $2462 \pm 565 \mathrm{pg} / \mathrm{ml}$ for the control, $10 \mu \mathrm{M}$ DMAQ-B1, and $100 \mu \mathrm{M}$ DMSO groups, respectively.

within 4 minutes and reached a statistical significant level at 21 minutes. DMAQ-B1 $(10 \mu \mathrm{M})$ stimulated a $240 \%$ increase in the peak effluent concentration of insulin at 21 minutes. In order to determine the dose-effect of DMAQ-B1 on insulin secretion, various concentrations of DMAQ-B1 $(1,5,10,15,20 \mu \mathrm{M})$ were infused into rat pancreas. As shown in Figure 2, insulin secretion was increased by DMAQ-B1 in a dose-dependent manner. DMAQ-B1 $(1,5,15$ and $20 \mu \mathrm{M})$ induced increases in the peak effluent insulin concentrations were $126 \%, 172 \%$, $256 \%$ and $291 \%$, respectively, above the basal control group. The insulin secretion response was declined after discontinuation of DMAQ-B1 perfusion.

\subsection{Effect of DMAQ-B1 on Glucose-Induced Insulin Secretion}

As shown in Figure 3, glucose $(10 \mathrm{mM})$ with or without DMAQ-B1 $(10 \mu \mathrm{M})$ were infused via in situ pancreatic perfusion. Glucose $(10 \mathrm{mM})$ alone induced a biphasic insulin secretory response. After the administration of DMAQ-B1 in perfusate containing $10 \mathrm{mM}$ glucose, the glucose-induced second phase of insulin secretion were enhanced compared with those with glucose alone $(\mathrm{P}<0.01)$. By comparing the AUCs of the percentage increase over baseline, DMAQ-B1 $(10 \mu \mathrm{M})$ enhanced $17.6 \%$ and $19.0 \%$ insulin secretion in the first and second phases of insulin secretion, respectively (Table 1).

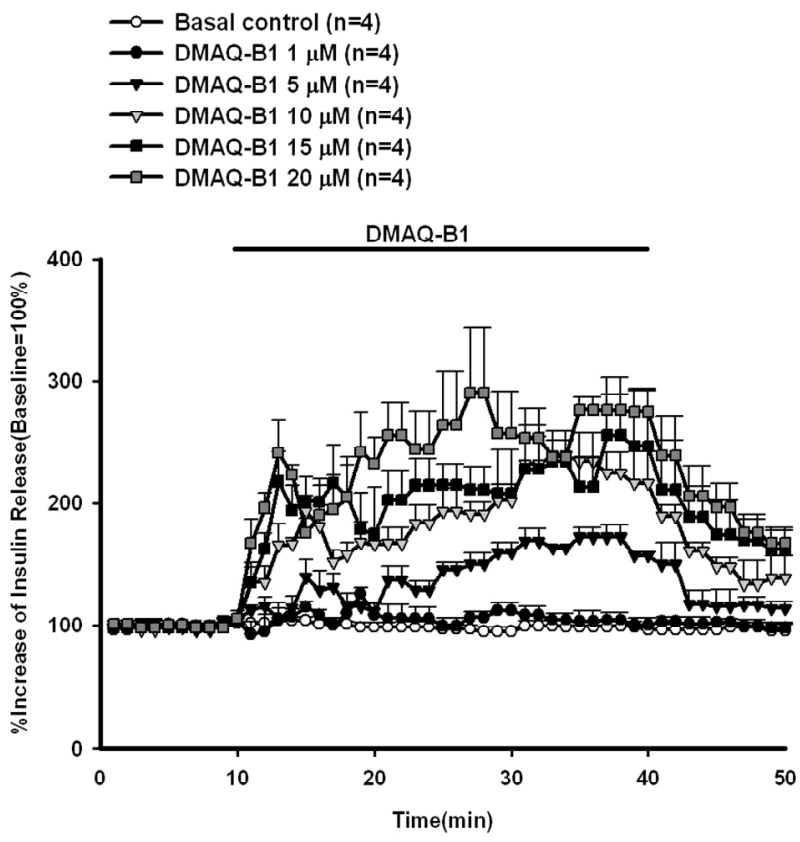

Figure 2. Dose-dependent effect of DMAQ-B1 on insulin secretion in the perfused rat pancreas. In pancreatic perfusion experiments, an equilibration period of $20 \mathrm{~min}$ preceded time 0 . After a baseline period of $10 \mathrm{~min}$, different dosage of DMAQ$\mathrm{B} 1$ was administered for $30 \mathrm{~min}$ followed by the basal medium $(\mathrm{KRB})$. Values are shown as means $\pm \mathrm{SE}(\mathrm{n}=4)$. The baseline effluent concentrations of insulin were $4172 \pm 277 \mathrm{pg} / \mathrm{ml}, 2556$ $\pm 296 \mathrm{pg} / \mathrm{ml}, 1733 \pm 259 \mathrm{pg} / \mathrm{ml}, 1385 \pm 265 \mathrm{pg} / \mathrm{ml}, 1381 \pm 74$ $\mathrm{pg} / \mathrm{ml}$ and $842 \pm 175 \mathrm{pg} / \mathrm{ml}$ for the control, 1, 5, 10, 15 and 20 $\mu \mathrm{M}$ DMAQ-B1 groups, respectively.

Table 1. Effect of DMAQ-B1 on glucose-induced first and second phases of insulin secretion.

\begin{tabular}{ccc}
\hline & $\begin{array}{c}\text { First phase } \\
(2-7 \mathrm{~min})\end{array}$ & $\begin{array}{c}\text { Second phase } \\
(8-30 \mathrm{~min})\end{array}$ \\
\hline Glucose $(10 \mathrm{mM})$ & $1945.6 \pm 259.8$ & $12534.3 \pm 890.7$ \\
$\begin{array}{c}\text { Glucose }(10 \mathrm{mM})+ \\
\text { DMAQ-B1 }(10 \mu \mathrm{M})\end{array}$ & $2287.3 \pm 377.9$ & $14927.6 \pm 1531.8$ \\
$\begin{array}{c}\text { \% increase over } \\
\text { glucose effect }\end{array}$ & $17.6 \%$ & $19.0 \%$ \\
\hline
\end{tabular}

Data are means $\pm \mathrm{SE}$, unless otherwise indicated. *AUC of the percentage increase over baseline. $\mathrm{P}<0.01$ vs. glucose group (Student's $\mathrm{t}$ test).

\subsection{Effect of PI3 Kinase Inhibitors on DMAQ-B1-Induced Insulin Release}

Two PI3 kinase inhibitors, LY294002 and wortmannin, were included in the perfusate to explore the possible signaling pathways leading to the effect of DMAQ-B1 on insulin secretion. As shown in Figure 4, LY294002 (3.9 $\mu \mathrm{M})$ and wortmannin $(100 \mathrm{nM})$ dramatically decreased DMAQ-B1-induced insulin secretion by $46.3 \%$ and $57.4 \%$, respectively. The results indicated a possible role of the PI3 kinase pathway involving the effect of DMAQ-B1 on insulin secretion. In Figures 5 and $\mathbf{6}$, 


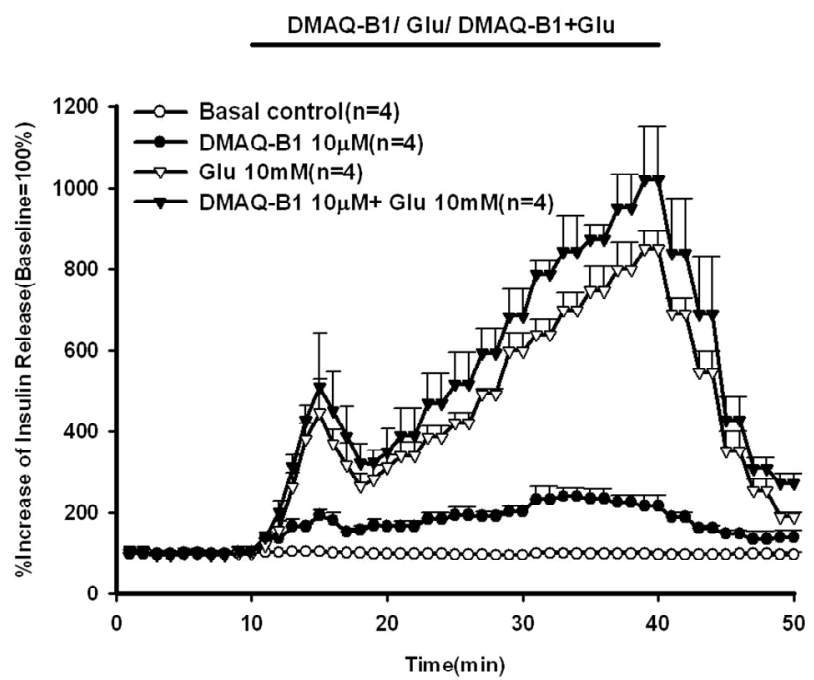

Figure 3. Effect of $10 \mu \mathrm{M}$ DMAQ-B1 in the medium containing $10 \mathrm{mM}$ glucose on insulin secretion in the perfused rat pancreas. In pancreatic perfusion experiments, an equilibration period of $20 \mathrm{~min}$ preceded time 0 . After a baseline period of 10 min, $10 \mu \mathrm{M}$ DMAQ-B1 with or without $10 \mathrm{mM}$ glucose was administered for $30 \mathrm{~min}$ followed by basal medium perfusion. Values are means $\pm S E(n=4)$. The baseline effluent concentrations of insulin were $4172 \pm 277 \mathrm{pg} / \mathrm{ml}, 1385 \pm 265 \mathrm{pg} / \mathrm{ml}, 634$ $\pm 156 \mathrm{pg} / \mathrm{ml}$ and $836 \pm 194 \mathrm{pg} / \mathrm{ml}$ for the control, $10 \mu \mathrm{M}$ DMAQ-B1, $10 \mathrm{mM}$ glucose and $10 \mu \mathrm{M}$ DMAQ-B1 + $10 \mathrm{mM}$ glucose groups, respectively.

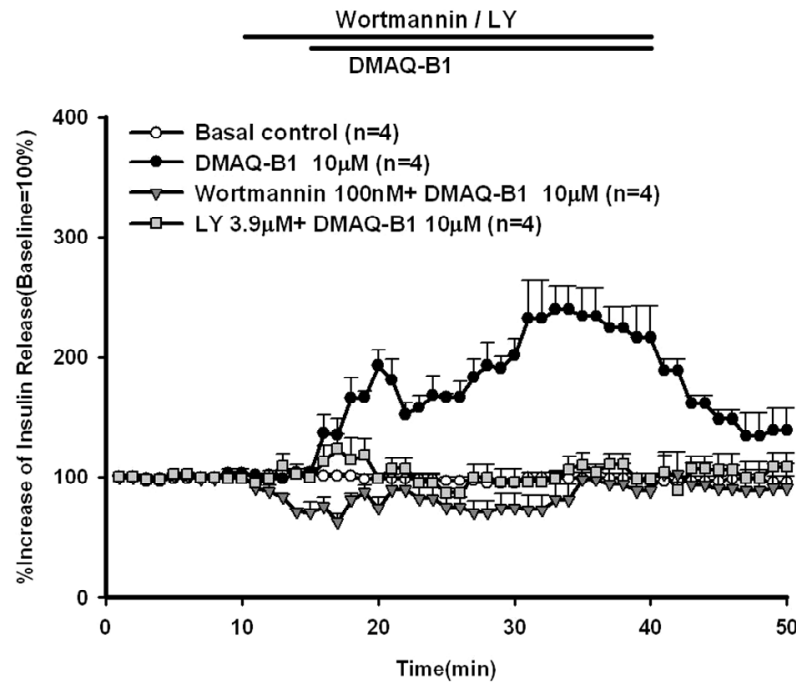

Figure 4. Effect of LY294002 or wortmannin on DMAQ-B1induced insulin release in the perfused rat pancreas. In pancreatic perfusion experiments, an equilibration period of $20 \mathrm{~min}$ preceded time 0 . After a baseline period of $10 \mathrm{~min}, 3.9 \mu \mathrm{M}$ LY294002 or $100 \mathrm{nM}$ wortmannin was administered for $5 \mathrm{~min}$, and then $10 \mu \mathrm{M}$ DMAQ-B1 was added in the medium for 30 min followed by basal medium perfusion. Values are means \pm $\mathrm{SE}(\mathrm{n}=4)$. The baseline effluent concentrations of insulin were $4172 \pm 277 \mathrm{pg} / \mathrm{ml}, 1385 \pm 265 \mathrm{pg} / \mathrm{ml}, 2871 \pm 253 \mathrm{pg} / \mathrm{ml}$ and $3179 \pm 642 \mathrm{pg} / \mathrm{ml}$ for the control, $10 \mu \mathrm{M}$ DMAQ-B1, $10 \mu \mathrm{M}$ DMAQ-B1 + $3.9 \mu \mathrm{M}$ LY294002 and $10 \mu \mathrm{M}$ DMAQ-B1 + 100 $\mathrm{nM}$ wortmannin groups, respectively.

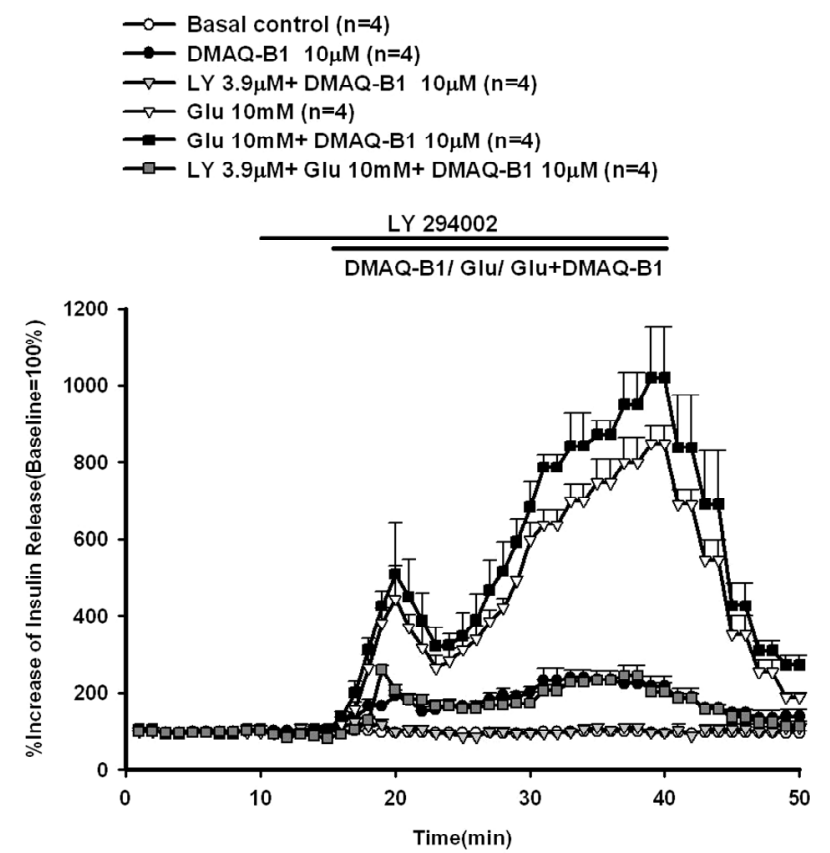

Figure 5. Effect of LY294002 on DMAQ-B1- or DMAQ-B1 mixed with $10 \mathrm{mM}$ glucose-induced insulin release in the perfused rat pancreas. In pancreatic perfusion experiments, an equilibration period of 20 min preceded time 0 . After a baseline period of $10 \mathrm{~min}, 3.9 \mu \mathrm{M}$ LY294002 was administered for 5 min, and then $10 \mu \mathrm{M}$ DMAQ-B1 or $10 \mu \mathrm{M}$ DMAQ-B1 with 10 $\mathrm{mM}$ glucose was added in the medium for 30 min followed by basal medium perfusion. Values are means \pm SE $(n=4)$. The baseline effluent concentrations of insulin were $4172 \pm 277$ $\mathrm{pg} / \mathrm{ml}, 1385 \pm 265 \mathrm{pg} / \mathrm{ml}, 2871 \pm 253 \mathrm{pg} / \mathrm{ml}, 634 \pm 156 \mathrm{pg} / \mathrm{ml}$, $836 \pm 194 \mathrm{pg} / \mathrm{ml}$ and $2670 \pm 376 \mathrm{pg} / \mathrm{ml}$ for the control, $10 \mu \mathrm{M}$ DMAQ-B1, $3.9 \mu \mathrm{M}$ LY294002 + $10 \mu \mathrm{M}$ DMAQ-B1, $10 \mathrm{mM}$ glucose, $10 \mathrm{mM}$ glucose $+10 \mu \mathrm{M}$ DMAQ-B1 and $3.9 \mu \mathrm{M}$ LY294002 + 10 mM glucose $+10 \mu \mathrm{M}$ DMAQ-B1 groups, respectively.

LY294002 $(3.9 \mu \mathrm{M})$ or wortmannin $(100 \mathrm{nM})$ were perfused before DMAQ-B1 with $10 \mathrm{mM}$ glucose, LY294002 or wortmannin inhibited glucose $(10 \mathrm{mM})$ mixed with DMAQ-B1-induced insulin secretion by $70.3 \%$ and $79.0 \%$, respectively.

\section{DISCUSSION}

In 1999, through extensive screening of over 50,000 mixtures of synthetic compounds and natural products, Zhang et al. identified and isolated a small molecular IR activator, demethylasterriquinone B-l (DMAQ-B1) from a fungal extract (Pseudomassaria sp.) by using Chinese hamster ovary cells expressed human IR [1]. DMAQ-B1 has greater activity 10 -fold selectivity for insulin receptor tyrosine kinase than insulin-like growth factor receptor (IGHF-IR), epidermal growth factor receptor (EGFR) and platelet-derived growth factor receptor (PDGFR) [13]. Zhang et al. also found that the interaction of DMAQ-B1 with IR kinase domain appears to alter the 


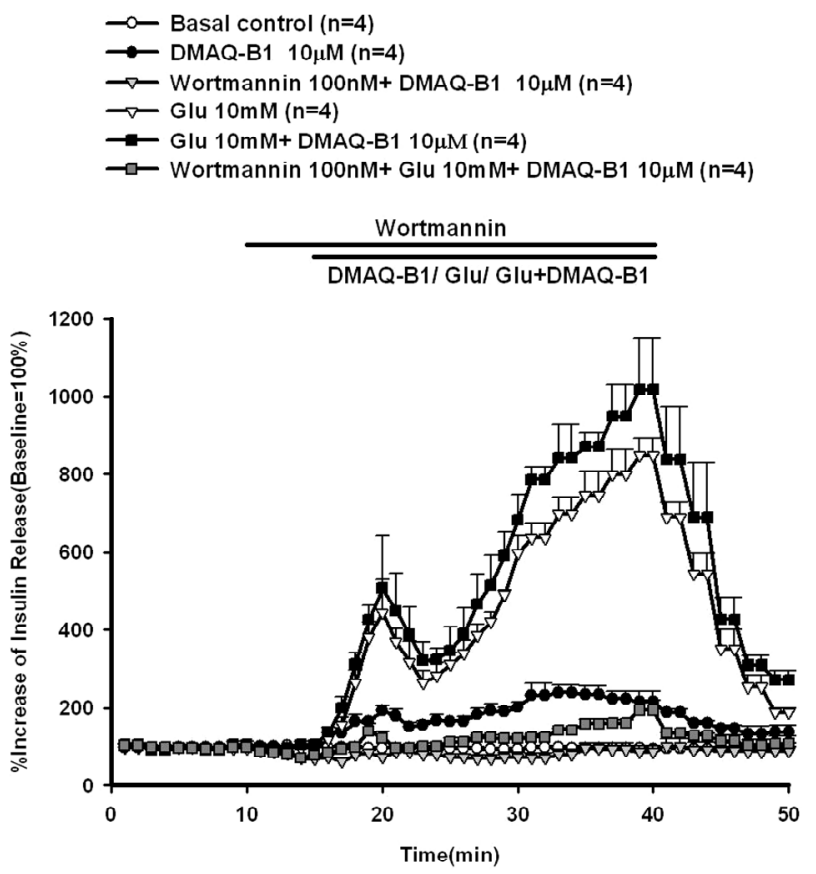

Figure 6. Effect of wortmannin on DMAQ-B1- or DMAQ B1 mixed with $10 \mathrm{mM}$ glucose-induced insulin release in the perfused rat pancreas. In pancreatic perfusion experiments, an equilibration period of 20 min preceded time 0 . After a baseline period of $10 \mathrm{~min}, 100 \mathrm{nM}$ wortmannin was administered for 5 min, and then $10 \mu \mathrm{M}$ DMAQ-B1 or $10 \mu \mathrm{M}$ DMAQ-B1 with 10 $\mathrm{mM}$ glucose was added in the medium for 30 min followed by basal medium perfusion. Values are means \pm SE $(n=4)$. The baseline effluent concentrations of insulin were $4172 \pm 277$ $\mathrm{pg} / \mathrm{ml}, 1385 \pm 265 \mathrm{pg} / \mathrm{ml}, 3179 \pm 742 \mathrm{pg} / \mathrm{ml}, 634 \pm 156 \mathrm{pg} / \mathrm{ml}$, $836 \pm 194 \mathrm{pg} / \mathrm{ml}$ and $5439 \pm 1912 \mathrm{pg} / \mathrm{ml}$ for the control, $10 \mu \mathrm{M}$ DMAQ-B1, $100 \mathrm{nM}$ wortmannin + $10 \mu \mathrm{M}$ DMAQ-B1, $10 \mathrm{mM}$ glucose, $10 \mathrm{mM}$ glucose $+10 \mu \mathrm{M}$ DMAQ-B1 and $100 \mathrm{nM}$ wortmannin $+10 \mathrm{mM}$ glucose $+10 \mu \mathrm{M}$ DMAQ-B1 groups, respectively.

conformation of the protein in the region encompassing the ATP binding site [1].

DMAQ-B1 also stimulated glucose uptake in rat primary adipocytes and in isolated soleus muscle from lean mice [1]. In addition, DMAQ-B1 dose-dependently increased glucose transport in 3T3L1 adipocytes [2]. Therefore, DMAQ-B1 can increase glucose uptake in peripheral tissues. In 2002, Roper et al. found that DMAQ-B1 dose-dependently induced intracellular calcium release in CD1 (ICR) mice and C57B1/6 mice pancreas [4]. The pretreatment of thapsigargin reduced the DMAQ-B1induced intracellular calcium release [4]. They also found that nifidipine can decrease DMAQ-B1-induced calcium increase by $33 \% \pm 6 \%$. It revealed that DMAQB1 induced $\mathrm{Ca}^{2+}$ entry through voltage-dependent $\mathrm{Ca}^{2+}$ channel [4]. In addition, $10 \mu \mathrm{M}$ DMAQ-B1 can stimulate $119 \% \pm 25 \%$ insulin release in IRS- $1+/+$ mice, whereas, $10 \mu \mathrm{M}$ DMAQ-B1 can only stimulate $1.3 \% \pm 0.1 \%$ insulin release in IRS-1-/- mice [4].
Zhang et al. found that oral administration of DMAQ$\mathrm{Bl}$ dose-dependently reduced blood glucose concentration in ob/ob mice. DMAQ-Bl also improved the glucose tolerance and reduced insulin concentration in $\mathrm{ob} / \mathrm{ob}$ mice [1]. In 2004, Strowski et al. found that oral DMAQB1 $(11.5 \mathrm{mg} / \mathrm{kg})$ for 3 weeks could reduced postprandial blood glucose levels by approximately $50 \%$ in STZ-induced type 2 diabetic mellitus C57BL/6 mice fed with high fat diet [5].

Our results showed that DMAQ-B1 directly stimulated insulin release in normal rat pancreas in a dose-dependent manner. The administration of DMAQ-B1 in $10 \mathrm{mM}$ glucose perfusate enhanced glucose-induced insulin secretion to $1019 \%$ compared with those in the perfusion experiments with DMAQ-B1 alone by $240 \%$ and glucose alone by $850 \%$.

Zhang et al. found that DMAQ-B1 phosphorylated insulin receptor beta subunit and insulin receptor substrate-1 (IRS-1) in CHO.IR cells and activated PI 3kinase and AKT [1]. Ding et al. reported that DMAQ-B1 could phosphorylate p70S6 kinase in CHO.IR cells [3]. P70 S6 kinase is another key enzyme downstream of the PI3-kinase pathway, and wortmannin can inhibit DMAQ$\mathrm{B} 1$ induced phosphorylation of p70S6 kinase [3].

There are two specific PI3 kinase inhibitors, wortmannin and LY294002. Wortmannin was produced from penicillium wortmannin and LY294002 was designed from flavonoid quercetin as a synthetic PI3 kinase inhibitor [9]. Although the IC50 of LY294002 is about 500 -fold higher than that of wortmannin, LY294002 is widely used in cell biology as a specific PI3K inhibitor because it is much more stable in solution than wortmannin [10]. The results showed that LY294002 $(3.9 \mu \mathrm{M})$ or wortmannin $(100 \mathrm{nM})$ inhibited DMAQ-B1- induced insulin secretion by $46.3 \%$ and $57.4 \%$. LY294002 (3.9 $\mu \mathrm{M})$ or wortmannin $(100 \mathrm{nM})$ also inhibited glucose mixed with DMAQ-B1-induced insulin secretion by $70.3 \%$ and $79.0 \%$, respectively. Pharmaceutical intervention aimed at augmenting insulin receptor function ultimately may prove beneficial as a novel therapeutic option in patients with diabetes [11].

All the results suggested that DMAQ-B1 directly stimulated insulin secretion in a slow release pattern in normal rat pancreas. In addition, glucose-induced insulin secretion was enhanced by DMAQ-B1. The results also showed that LY294002 or wortmannin inhibited DMAQB1-induced insulin secretion and glucose mixed with DMAQ-B1-induced insulin secretion. Therefore, the effect of DMAQ-B1 may mediate through the activation of PI3 kinase pathway to stimulate insulin secretion.

\section{REFERENCES}

[1] Zhang, B.B., Salituro, G.M., Szalkowski, D., Li, Z., 
Zhang, Y., Royo, I., Vilella, D., Diez, M.T., Pelaez, F., Ruby, C., Kendall, R.L., Mao, X., Griffin, P., Calaycay, J., Zierath, J.R., Heck, J.V., Smith, R.G. and Moller, D.E. (1999) Discovery of a small molecule insulin mimetic with antidiabetic activity in mice. Science, 284, 974-977. doi:10.1126/science.284.5416.974

[2] Webster, N.J., Park, K. and Pirrung, M.C. (2003) Signaling effects of demethylasterriquinone B1, a selective insulin receptor modulator. Chembiochem, 4, 379-385. doi:10.1002/cbic.200200468

[3] Ding, V.D.H., Qureshi, S.A., Szalkowski, D., Zhihua, L. I., Biazzo-ashnault, D.E., XIE, D., Liu, K., Jones, A.B., Moller, D.E. and Zhang, B.B. (2002) Regulation of insulin signal transduction pathway by a small-molecule insulin receptor activator. Biochemical Journal, 367, 301-306. doi:10.1042/BJ20020708

[4] Roper, M.G., Qian, W.J., Zhang, B.B., Kulkarni, R.N., Kahn, C.R. and Kennedy, R.T. (2002) Effect of the insulin mimetic L-783, 281 on intracellular $\mathrm{Ca}^{2+}$ and insulin secretion from pancreatic beta-cells. Diabetes, 51, S43S49. doi:10.2337/diabetes.51.2007.S43

[5] Strowski, M.Z., Li, Z., Szalkowski, D., Shen, X., Guan, X.M., Juttner, S., Moller, D.E. and Zhang, B.B. (2004) Small molecule insulin mimetic reduces hyperglycemia and obesity in a non-genetic mouse model of type 2 diabetes. Endocrinology, 145, 5259-5268. doi:10.1210/en.2004-0610

[6] Velliquette, R.A., Friedman, J.E., Shao, J., Zhang, B.B. and Ernsberger, P. (2005) Therapeutic actions of an insulin receptor activator and a novel peroxisome proliferator-activated receptor $\gamma$ agonist in the spontaneously hypertensive obese rat model of metabolic syndrome X. J. Journal of Pharmacology and Experimental Therapeutics, 314, 422-430. doi:10.1124/jpet.104.080606

[7] Grodsky, G.M. and Fanska, R.E. (1975) The in vitro perfused pancreas. Methods in Enzymology, 39, 364-372. doi:10.1016/S0076-6879(75)39033-2

[8] Hale, C.N. and Randle, P.J. (1963) Immunoassay of insulin with insulin antibody precipitate. Biochemical Journal, 88, 137-146.

[9] Vlahos, C.J., Matter, W.F., Hui, K.Y. and Brown, R.F. (1994) A specific inhibitor of phosphatidylinositol 3kinase, 2-(4-morpholinyl)-8-phenyl-4H-1-benzopyran-4-one (LY294002). The Journal of Biological Chemistry, 269, 5241-5248.

[10] Walker, E.H., Pacold, M.E., Perisic, O., Stephens, L., Hawkins, P.T., Wymann, M.P. and Williams, R.L. (2000) Structural determinants of phosphoinositide 3-kinase inhibition by wortmannin, LY294002, quercetin, myricetin, and staurosporine. Molecular Cell, 6, 909-919. doi:10.1016/S1097-2765(05)00089-4

[11] Salituro, G.M., Pelaez, F. and Zhang, B.B. (2001) Discovery of a small molecule insulin receptor activator. Recent Progress in Hormone Research, 56, 107-126. doi:10.1210/rp.56.1.107 